\title{
The Choice of Ways to Integrate the Socialist Core Value System Into the Ideological and Political Education in Colleges and Universities
}

\author{
Xiaowen Luo ${ }^{1, \text { a }}$ \\ ${ }^{1}$ Jiangxi Vocational technical College of Industry \&Trade, jiangxi, nanchang, 330038 \\ a739960103@qq.com

\begin{abstract}
Colleges and universities should closely link the socialist core value system with the ideological and political education in Colleges and universities, actively explore the efficient mode of infiltrating the socialist value system into the ideological and political education of college students, enhance the cooperation ability of students in the socialist ideology, and cultivate all-round talents for the construction of socialism with Chinese characteristics.
\end{abstract}

Keywords: socialist core value system, Integration, Ideological and political education in Colleges and Universities

\section{社会主义核心价值体系融入高校思政教育的途径选择}

\author{
罗晓雯 ${ }^{1, a}$
}

\author{
${ }^{1}$ 江西工业贸易职业技术学院 江西 南昌 330038 \\ a739960103@qq.com
}

\section{摘要:}

高校要将社会主义核心价值体系和高校思想政治教育紧密联系列为重点范围内, 主动摸索将社会主义价值体 系渗透进大学生思想政治教育的高效模式, 提升学生在社会主义意识形态方面的合作能力, 为中国特色社会 主义事业建设培养全能型人才。

关键词：社会主义核心价值体系；融入；高校思政教育

\section{1. 社会主义核心价值体系的基本内涵及其融} 人高校思想政治教育的目标要求

\section{1. 社会主义核心价值体系的基本内涵}

社会主义核心价值观体系作为社会主义制度的 内部灵魂和精华, 展现了社会主义意识形态。社会 主义基本内容主要包含四部分, 即马克思主义指导 思想、中国特色社会主义共同理想、以爱国主义为 核心的民族精神和以改革创新为核心的时代精神和 社会主义荣辱观。

在社会主义核心价值体系中, 马克思主义指导 思想作为其精华, 中国特色社会主义共同理想作为
其主旨, 以爱国主义为核心的民族精神和以改革创 新为核心的时代精神作为其精髓, 社会主义荣辱观 作为其基奠，共同作用于社会主义核心价值观体系。 社会主义核心价值体系不仅体现了社会主义意识形 态的重点和时代的需求, 而且在经济体制革新、社 会结构变化、利益格局调度和思想观念更新的背景 下，是社会不同行业和不同利益群体思想的凝聚力。

\section{2. 把社会主义核心价值体系融入高校思想 政治教育的目标要求}

在我国目前社会主义教育的特性和目标的影响 下，在高校思想政治教育教学过程中引入社会主义 核心价值体系是至关重要的。我国是一个由中国共 产党带领的社会主义国家, 所以在高校进行思想政 
治教学实践过程中, 要将社会主义作为指引。所以, 要想在高校思想政治教育教学过程中很好地引入社 会主义核心价值体系，就要合理使用马克思主义， 让其指引学生使用科学的世界观和方法论, 以此来 更好地了解世界, 同时将中国特色社会主义共同理 想融入到教育教学中, 帮助学生形成崇高的理想, 另外将以爱国主义为核心的民族精神和以改革创新 为核心的时代精神融入到教育教学中, 让学生养成 良好的信念和精神, 将社会主义荣辱观融入到思想 政治教学中，增强学生在思想道德方面的素养，让 社会主义核心价值体系内化于学生的心中, 同时让 学生外化于行动中。

\section{2. 社会主义核心价值体系融人高校思想政治 教育的必要性}

现阶段, 在全球化背景之下, 我国意识形态领 域指导思想的一元性与文化观念、价值取向的多样 性共同存在的现实状况, 在我国意识形态领域, 为 我们发展与巩固马克思主义的指导地位带来了新的 挑战。许多高校在马克思主义和非马克思主义之间 也存在着意识形态的争论, 在处理多元化和一元化 关系的方面, 存在着一系列问题。有些教师和学生 有着下面这些问题: 在思想方面, 他们比较崇尚西 方的洋教条, 对于马克思主义的指导地位较为忽视, 比较偏向于意识形态方面的多元化; 价值取向方面, 他们不重视信念、责任、理想与义务, 过度追求地 位、报酬、名利与权利; 在人才培养方面, 在评价 和考核干部、人才方面, 重视在学术方面的造诣, 并没有太过注重政治标准; 在精神文明建设上, 建 设学校文明的时候过度重视对于娱乐氛围的创造, 忽视了在政治思想导向方面的意识，甚至，非马克 思主义和反马克思主义的思想, 都通过新的方式展 现了出来。

即使这些是特殊情况, 然而其本质却是弱化马 克思主义意识形态在高校的重要作用。因此, 若马 克思主义理论没能主导于高校思想文化营地, 其他 的思潮可能就会替代马克思主义理论。若破坏了马 列主义、毛泽东思想和邓小平理论这些主导思想, 破坏了建设有中国特色社会主义的共同理想, 可能 就会使得社会思想价值观念不正、社会混乱, 对国 家、党和民族来说是十分不利的。

\section{1. 加强理想道德建设的需要}

总体来讲, 高校学生有着良好的思想道德状况, 部分学生对国家的命运与前途很关心, 有着较为远 大的人生理想, 努力学习科学与知识, 希望能够成 长成才。但因为受到来自于市场经济的影响, 有些 学生在思想道德方面出现了许多应该受到重视的问 题, 举例而言: 社会责任感弱化, 人生价值取向出 现偏差; 法制观念以及集体观念淡薄, 过度注重把
自己作为中心，学生的文明素质较弱; 没有形成良 好的学风, 在考试的时候存在着作弊现象。

目前, 思维活跃、多种思想和文化联系是这个 时代的特征, 在这样的情况下, 很多思想观念是很 难被辨别是非的, 另外主流意识和非主流意识也会 出现错位的现象。要想让目前的大学生拥有正确的 政治观念和价值观念, 就要对上述的问题做出进一 步的规范和引导。所以, 针对这样的问题, 在高校 思想政治教育教学中引入社会主义核心价值体系就 显得尤为重要, 能够全面位提升学生的综合素养。

\section{2. 增强思想政治教育吸引力的需要}

社会主义核心价值体系融人思想政治教育也有 助于增进思想政治教育的人本性。当代大学生的思 想观念、道德意识、价值取向越来越呈现出层次性 和多样化的特征, 而社会主义核心价值体系是一个 能适应不同层次需求的价值观体系，它既尊重差异、 扩大共识, 又能包容多样、鼓励先进。把社会主义 核心价值体系融入思想政治教育之中，才能增强思 想政治教育的吸引力, 营造一种适合时代特点的精 神文化氛围。

\section{3. 构建和谐校园文化的需要}

随着改革开放的不断深入，西方文化接踵而来, 高校是如今新思想的出现、发展、传播和聚集的区 域, 会被西方文化所影响。西方文化不但使高校思 政教师的工作产生了影响，还对社会主义和谐校园 文化创建起到了阻碍的作用。除此之外, 步入 21 世 纪以来, 因为高等教育资源的优化配置, 一些院校 在拓宽办学专业和规模的时候, 忽视了正确的教学 模式和教学资源稀缺等因素和学校的计划不相符合, 学校以至于一味的追求经济的发展进步, 从而造成 了学校和政府、学校和教师学生, 教学和学习等之 间的发展不符合社会现实, 进一步导致了校园文化 创建面临了新的发展难题。

所以，在创建良好校园文化的过程中，只有真 正的了解社会主义核心价值体系，才可以发展共同 的理想, 强化师生的情感; 才可以创造出良好的與 论环节, 发展师生之间的良好心态。在社会主义制 度中社会主义核心价值体系是精神之魂, 推动了社 会主义意识形态的进步。在和谐校园文化创建期间 若没有社会主义核心价值体系的指引，便容易失去 发展方向。 


\section{3. 社会主义核心价值体系融人高校思想政治 教育的主要途径}

\section{1. 提高宣传教育的吸引力, 增强大学生对 社会主义核心价值体系的认同感}

要让两课这种课堂模式充分发挥教化作用，传 播积极的价值观。

渗透使课堂教育的首要方式。要把知识渗透到 学生心里, 否则思政课堂的作用微乎其微。两课的 形式可以帮助马克思主义在大学生之间的传播, 让 大学生深入学习社会主义核心价值观，是让社会主 义核心价值观与高等教育互相融合的重要方法, 深 入解释, 详细分析, 让大学生能够理解并践行社会 主义核心价值观, 在未来的生活中能够运用这种思 想武器。大学生要理解社会主义核心价值观的意义, 明白社会主义核心价值观是新时代中国共产党为了 帮助中华民族伟大复兴提出的, 让这种思想在社会 的中流砥柱中获得实践。

其次, 要让学生的主体性得到充分体现。

把社会主义核心价值观深刻渗透到大学生群体 中, 其实就是思想渗透。一部分, 上课时老师应该 慢慢诱导学生, 生活中老师要以实际行动来传播这 种思想, 关爱、爱护学生, 让老师和学生的关系更 亲近, 学生就会亲近老师, 并且相信老师讲的道理。 另一部分要让实际行动和课本知识统一起来, 这是 思政课老师传播这种思想的重要方法, 要注意内涵 和表达形式的共同发展, 老师要有高尚的道德品质 让学生尊敬他们, 从而给学生们传达这种思想价值 观, 不但要发挥思想的力量, 条理清晰, 也要形成 高尚的品格, 学生要学习这种思想, 首先老师要发 挥领导作用, 践行这种行为, 形成这种思维方式, 这样才能表现这种价值观的实用性和可行性。

\section{2. 促进理论教育与实践教育相结合, 增强社 会主义核心价值体系的实效性}

学校和教师在开展思政教学时需要认识到该机 制的重要性，将社会主义核心价值观念与思政教育 有效结合在一起, 充分发挥出思政教学的价值, 使 学生通过课堂学习来深入地了解社会主义核心价值 理念。教师在开展思政教学时不仅要注重开展理论 知识教学, 还需要开展实践教学, 将理论教学与实 践教学有效结合在一起。

首先, 学校和教师开展思政教育时可以开展多 样化的教学活动, 比如: 鼓励学生参加艺术比赛、 组织学生参观博物馆, 使学生在参加这些活动时来 了解和感受中国取得的重大成果和改变。教师在学 生参加这些教学活动时可以为学生讲解近几年中国 人民在生活方式和工作方式上发生的改变, 通过讲 解这些内容来提高学生对中国共产党的认同感和自
信心，使学生可以更加直观地感受社会主义机制的 优势。

其次, 学校和教师开展思政教育时可以开展多 样化的实践活动, 比如: 组织学生参加军训活动、 鼓励学生积极主动地参加志愿服务工作, 这些实践 活动可以使学生在实践中体验到社会责任感的重要 性, 可以让学生在实践活动中深入了解社会主义核 心价值观念, 提高学生对社会主义制度的认同感和 自信心。教师要鼓励学生做中华民族优秀文化的传 承者和弘扬者, 以此来提高学生的道德素养。

\section{3. 营造和谐校园文化环境, 增强社会主义核 心价值体系的渗透性}

\section{3. 1. 应创造科学和谐的校园精神氛围}

大学生活在学生的成长过程中起着十分重要的 位置, 它不仅影响着学生的三观理念, 还影响着学 生的学习生活和生活方式。学校需要为学生营造良 好的学习环境和成长环境, 通过举办一些活动和开 展一些课程来提高学生辨别好坏的能力, 提高学生 的思想素养。

\section{3. 2. 应制定能够体现校风. 学风的校训}

学校的灵魂在于校训, 从校训中可以看出一个 学校的教学原则和任务, 对教育工作的开展起着指 导作用。每个高校都会根据自身实际设置校训, 并 印刻在石碑上, 放在学校的中心位置, 不知不觉地 影响着全校的师生。

\section{3. 3. 创建丰富多彩的校园文化环境}

目前的大学生思想开明，精神的发展展现出其 多元化、独特性的特征，丰富的校园文化让学生们 可以在多种活动过程中发现自身的价值，从而调动 学生的积极性和主动性, 强化学生的自尊心和责任 心。

所以学校应该找到大学生的特点, 及时实施多 样化、丰富化的各类课外活动, 丰富大学生的知识 范围, 培养他们养成较高的创新意识。

\section{4. 结论:}

在社会主义核心价值体系中，社会主义核心价 值观是其的根本性质和基本特征。在高校的思政教 育课程中加入社会主义核心价值体系可以加强理论 和实践的想几个，创造良好的校园文化氛围，从而 维护意识形态领域的安全, 强化学生的思想道德建 设. 


\section{REFERENCES}

[1] Zhu Jiao, Li Xue, Liu Tong, et al. Based on the "great ideological and political" perspective, Xi Jinping's new era of China's socialist ideology "three progressive" teaching methods research [J]. contemporary education practice and teaching research (Electronic Journal), 2018, (12): 688699.

[2] General Office of the Standing Committee of the National People's Congress, Literature Research Office of the Central Committee of the Communist Party of China. Selected works of the people's Congress system (Volume I) [g]. Beijing: China democracy and legal system press, 2015

[3] Xi Jinping stressed at the National Conference on Ideological and political work in Colleges and Universities: "Ideological and political work goes through the whole process of education and teaching, creating a new prospect for the development of higher education in China [N]. People's daily, 201612-09 (01).

[4] Xi Jinping. With the Central Party School Secretary of the county Party committee seminar, the students stressed that Jiao Yulu, a secretary of the county Party committee, has a sense of responsibility in the heart of the party. There is a sense of responsibility in the heart of N. Guangming Daily, 2016-01-13 (01).

[5] Sun Hongli, Liu Wenyong, Huang Bizhen, Yu Tiantian. Research on the ability elements of Ideological and political education of University Graduate Students under the new media environment [J]. Journal of Shenyang University: Social Science Edition, 2017, 19 (4): $472-476$

[6] Sun Xiaofeng. Inheriting and carrying forward fine family style, cultivating and bringing up new people of the times -- Thinking and Practice on a series of activities of family style culture into campus [J]. Journal of Chizhou University, 2019,33 (4): 1-5

[7] Xiao Yonghui, Li Yanbing Xi Jinping. The educational thoughts of youth values in the new era of socialism with Chinese characteristics: $[\mathrm{J}]$. Journal of Northeastern China Normal University: Philosophy and Social Sciences Edition, 2019,0 (5): 152-157.

[8] Xi Jinping. China wins the victory of building a welloff society in an all-round way and wins the great victory of socialism with Chinese characteristics in the new era: report on the nineteenth National Congress of the Communist Party of China [M].] Beijing: People's publishing house, 2017:41.

[9] Wu ye, Luo Guoji. The predicament and Path Exploration of Marxism Popularization in contemporary China [J]. Journal of Inner Mongolia Agricultural University: Social Science Edition, 2011, 13 (6): 274-27

[10] Tang Li, Yan Changli, Chen Lin, long Mei, Wu Wentao. Xi Jinping's teaching strategy research on the introduction of socialism with Chinese characteristics in the new era $[\mathrm{J}]$. J]. Journal of the Institute of education, China, 2019, 33 (6): 148 - 150.

[11] Du Zhixiong, Xiao Weidong. Adjusting the relationship between urban and rural areas with scientific theory and decision-making -- the Centennial exploration and practical experience of the Communist Party of China in adjusting the relationship between urban and rural areas [J] Chinese leadership science, 2021 (2): 31-37

[12] Zheng Zili, Zhou zuohan. Analysis on the current situation of promoting the popularization of Marxism in contemporary China by colleges and Universities -- Based on the empirical investigation of ordinary undergraduate colleges and universities in Changsha [J]. Journal of Social Sciences of Hunan Normal University, 2011, 40 (2): 135-139

[13] Zhou Liang, Chen Yuanqing, Shang Jie. Xi Jinping's effectiveness in the propaganda and education of China's socialist ideology in the new era [J]. Journal of China University of Petroleum, 2019 (3): 32 - 38.

[14] Zhou Liang, Pan Hong, Wang Xin. Xi Jinping's basic principles, main ways and general train of thought in China's new era of socialism with Chinese characteristics in the ideological and political classroom [J]. Journal of Kunming University of Science and Technology (SOCIAL SCIENCES), 2019 (6): 37 - 43

[15] Xiao hang. Xi Jinping's popularization of China's characteristic socialism in the new era: Based on the dimension of everyday life [J]. Journal of Baoji University of Arts and Sciences: Social Sciences Edition, 2019, 39 (4): 58 - 63.

[16] Jing Weiwei, Gong Jianhua. The popularization of Marxism in the new media era -- a study of discourse transformation based on Mass Communication [J]. Journal of Bohai University: Philosophy and Social Sciences, 2017, 39 (6): 131-135

[17] Wang Jingyun. The structure, operation and evaluation of the discourse field of external communication: a case study of the high level dialogue between the Communist Party of China and world political parties [J]. Journal of Suzhou University: Philosophy and Social Sciences, 2020, 41 (4): 79-85 